Journal of Engineering

journal homepage: www.joe.uobaghdad.edu.iq

Number 2 Volume 26 February 2020

Chemical, Petroleum and Environmental Engineering

\title{
The Optimum Reservoir Performance of Nahr Umr/Ratawi Oil Field
}

\author{
Mohammed Rashad Jemeel \\ Petroleum technology department \\ University of Technology \\ Najaf, Iraq \\ moh0780107801@gmail.com
}

\section{Dr.Samahr A. Lazium*}

Petroleum technology department

University of Technology

Baghdad, Iraq

samaher2013@yahoo.com

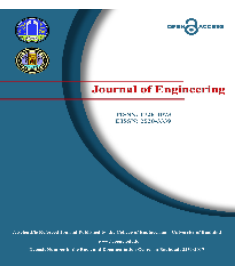

\section{ABSTRACT}

Reservoir study has been developed in order to get a full interesting of the Nahr Umr formation in Ratawi oil field. Oil in place has been calculated for Nahr Umr which was 2981.37 MM BBL. Several runs have been performed to get matching between measured and calculated of oil production data and well test pressure. In order to get the optimum performance of Nahr Umr many strategies have been proposed in this study where vertical and horizontal wells were involved in addition to different production rates. The reservoir was first assumed to be developed with vertical wells only using production rate of (80000-125000) STB/day. The reservoir is also proposed to produce using horizontal wells besides vertical wells with production rate of (80000-150000) STB/day. The best strategy was by adding 33 new vertical wells and 5 horizontal wells beside the 11 existing wells where the results show oil plateau of 9 years and 7 months and recovery factor of $3.4 \%$.

Key Words: reservoir model, matching, development strategies.

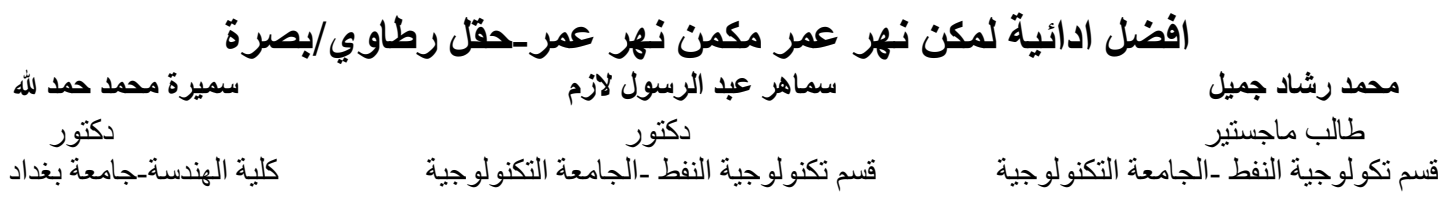

\section{الخلاصة}

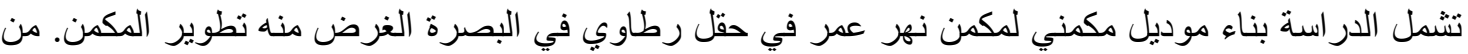

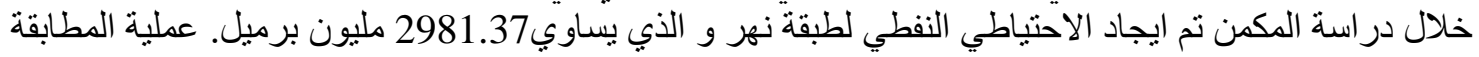
بين البيانات المحسوبة و المقاسة قد نكررت عدة مر ات لكي لكي يتم الحصول على تطابق تام لبيانات انتاج النفط ونطابق

*Corresponding author

Peer review under the responsibility of University of Baghdad.

https://doi.org/10.31026/j.eng.2020.02.04

2520-3339 (C) 2019 University of Baghdad. Production and hosting by Journal of Engineering.

This is an open access article under the CC BY4 license http://creativecommons.org/licenses/by /4.0/2.

Article received: 13/12/2018

Article accepted: 12/3/2019

Article published: 1/2/2020 


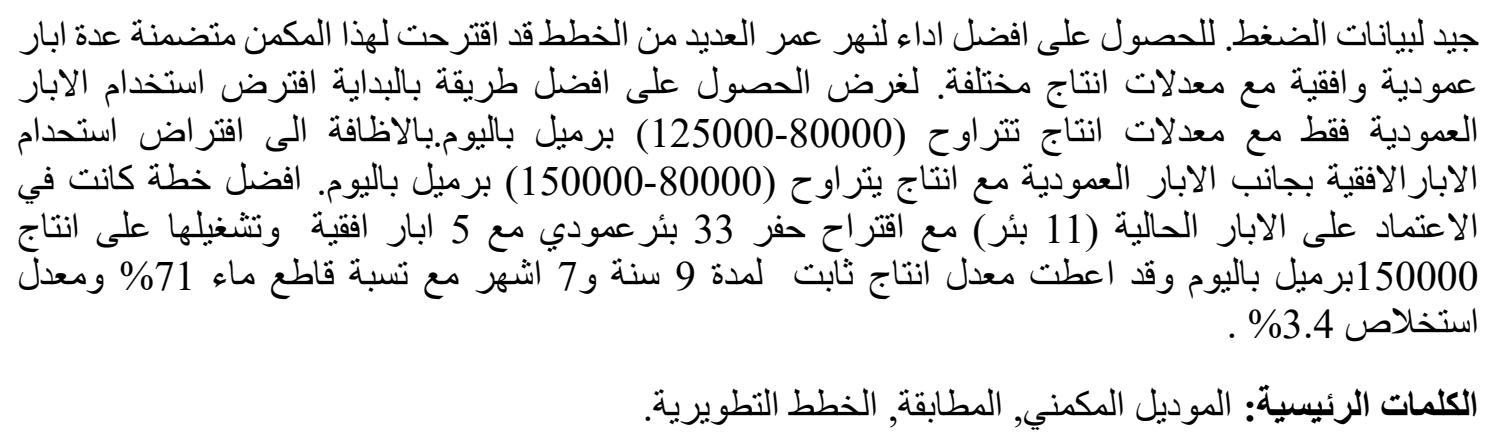

\section{INTRODUCTION}

Reservoir simulation may be defined as a tool used to predict reservoir performance in the future using multiple keys like mathematics, physics, reservoir managing, and programming by a computer. The simulation becomes unrivaled method to describe complex heterogeneous reservoir with multiple phases. (Alruri, et al., 2015) studied the reservoir model of Ratawi oil field of Fawaris formation in Saudi Arabia. The study includes estimating oil in place and distributing of remaining oil. The study used dynamic model to identify the infill and injection wells. (Dogru 2019) simulated fluid flow in a reservoir and well production rates with horizontal well or by multiple vertical wells. (Alireza Mollaei and Mojdeh Delshad, 2019) proposed water injection in order to increase production and pressure maintenance. Also predicting the performance of reservoir with water flooding in future was included in this study. History matching gave good agreement between field data and forecasting results. To get optimum performance in this study several steps have been proposed.

\section{RESERVOIR MODEL}

Reservoir model was built using Petrel software 2015.1 Re, (Schlumberger, 2018) which was the gate to export the model to black oil Eclipse 100 system where the total grid after building the model was 454308 cells. To get the goal of this study many data was required like fluid properties (oil density, oil formation volume factor ...etc), special core analysis data, initial conditions, irreducible water saturation, and rock compressibility.

\subsection{Irreducible Water Saturation $\left(\mathrm{S}_{\mathrm{wi}}\right)$}

Irreducible water saturation $\left(S_{w i}\right)$ has been determined by plotting water saturation and effective porosity obtained from well log data on the linear scale (Morris and Beggs, 1967). Hyperbola of points resulted as shown in Fig. 1 for the data of well Rt-20. Average $S_{\mathrm{wi}}$ for all wells was found to be 0.21 , Table 1 . 


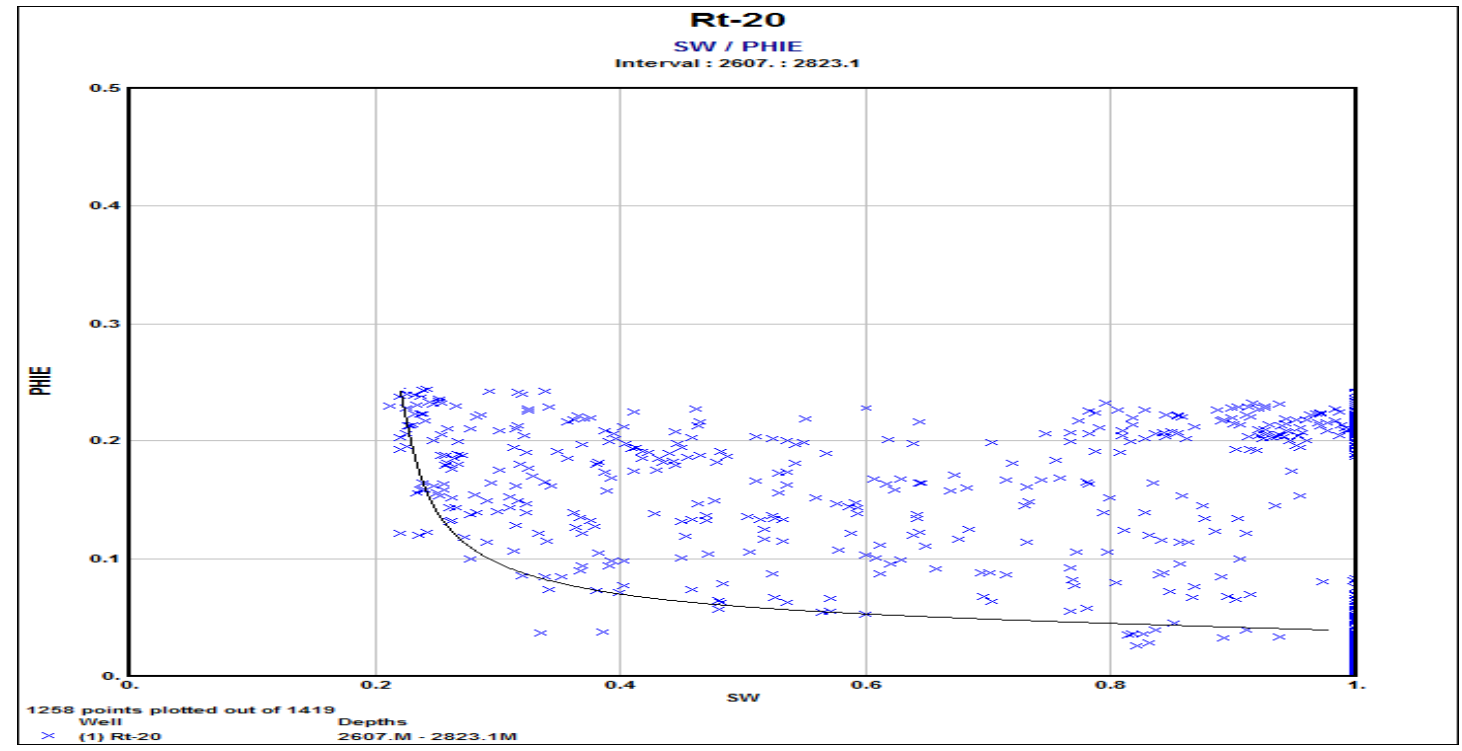

Figure 1. Irreducible water saturation determination of well Rt-20.

Table 1. Irreducible water saturation of several wells.

\begin{tabular}{|c|c|c|c|c|c|c|c|}
\hline Well no. & Rt-16 & Rt-17 & Rt-18 & Rt-20 & Rt-21 & Rt-22 & Averge \\
\hline $\mathrm{S}_{\mathrm{wi}}$ & 0.18 & 0.185 & 0.23 & 0.24 & 0.22 & 0.23 & 0.21 \\
\hline
\end{tabular}

\subsection{Initial Conditions}

\subsubsection{Initial reservoir pressure}

Initial reservoir pressure was provided by a well test file. Well test file of Rt-16 gives a 4248 psi (292.8 bar) as initial pressure for Nahr Umr / Ratawi oil field, (Hussian et al., 2016).

2.2.2 Water oil contact (WOC)

Water oil contact was determined from the interpretation process of well log data by observing the values of water saturation with depth of several wells. The WOC was found to be at $-2728 \mathrm{~m}$ for Nahr Umr formation, as shown in Table 2 and Fig. 2.

Table 2. Water oil contacts for several wells.

\begin{tabular}{|c|c|c|c|c|c|c|}
\hline Well name & Rt-16 & Rt-17 & Rt-18 & Rt-20 & Rt-21 & Rt-24 \\
\hline Owc(meter) & -2725.6 & -2718.9 & -2720.39 & -2730.3 & -2743.03 & -2730.42 \\
\hline
\end{tabular}




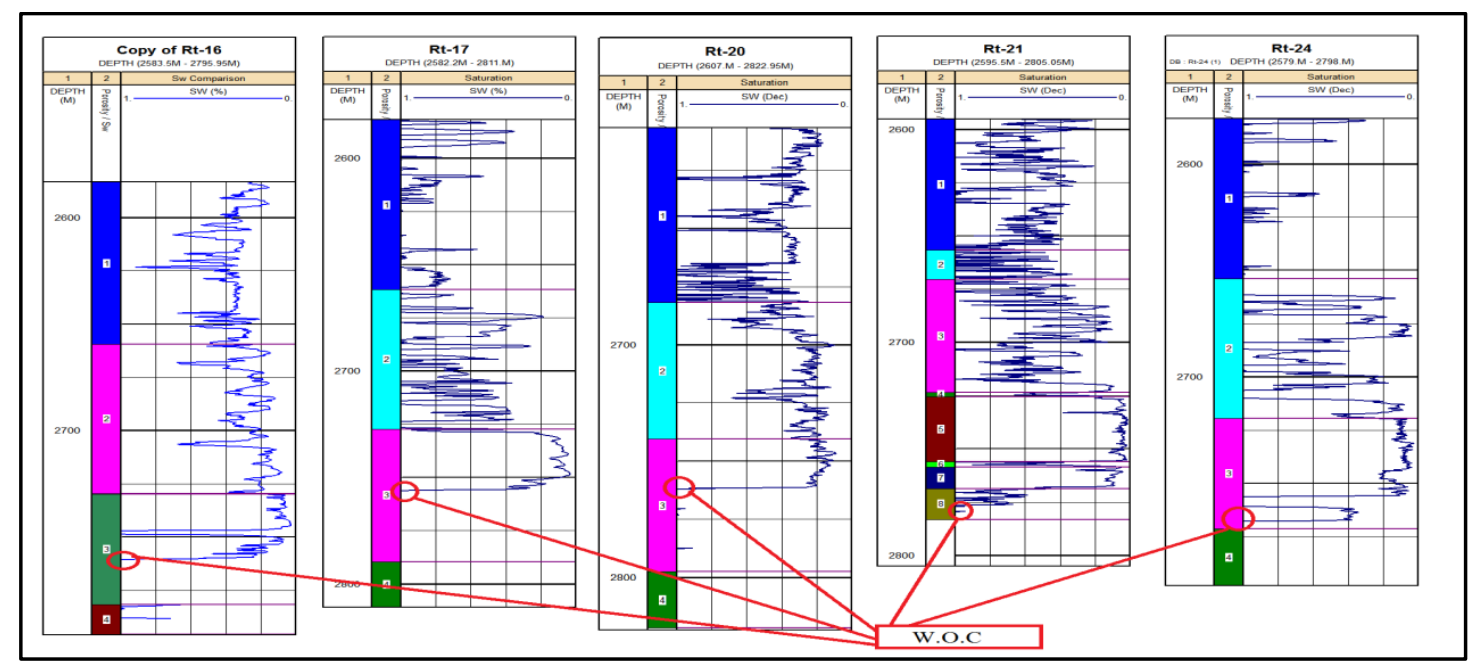

Figure 2. Water saturation vs. depth of different wells.

\subsection{Relative permeability}

Relative permeabilities data and capillary pressure were not available for Nahr Umr formation. Relative permeability compensated by Corey equation (1950), (Ahmed, and McDkinney, 2005) where Corey suggests several equations for oil water system. As shown in Eq.1 and Eq. 2, Corey exponent for oil and water is equal to 2 and $S_{\text {orw }}$ is equal to 0.27 . Oil relative permeability at irreducible water saturation $\left(\mathrm{k}_{\mathrm{ro}} @ \mathrm{~S}_{\mathrm{wi}}\right)$ and water relative permeability at residual oil saturation to water flooding $\left(\mathrm{K}_{\mathrm{rw}} @ \mathrm{~S}_{\mathrm{orw}}\right)$ are assumed as 0.6 and 0.3 respectively, (Jogemec, 2007), Table 3 and Fig. 3.

$$
\begin{aligned}
& K r o=(K r o)_{s w i}\left[1-\frac{S w-S w i}{1-S w i-S o r w}\right]^{n o} \\
& k r w=(k r w)_{s o r w}\left[\frac{s w-s w i}{1-s w i-s o r w}\right]^{n w}
\end{aligned}
$$

where

$\mathrm{K}_{\mathrm{rw}}$ : water relative permeability md.

Kro: oil relative permeability md.

$(\mathrm{Kro})_{\text {swi: }}$ oil relative permeability at residual water saturation.

$(\mathrm{krw})_{\text {sorw: }}$ water relative permeability at residual oil saturation.

Table 3. Relative permeabilities of oil- water system.

\begin{tabular}{|c|c|c|c|c|c|c|c|c|c|c|c|}
\hline sw & 0.21 & 0.26 & 0.32 & 0.38 & 0.44 & 0.498 & 0.55 & 0.61 & 0.67 & 0.73 & 1 \\
\hline krw & 0 & 0.003 & 0.014 & 0.033 & 0.059 & 0.092 & 0.13 & 0.18 & 0.23 & 0.3 & 1 \\
\hline kro & 0.6 & 0.47 & 0.36 & 0.26 & 0.185 & 0.118 & 0.066 & 0.029 & 0.007 & 0 & 0 \\
\hline
\end{tabular}




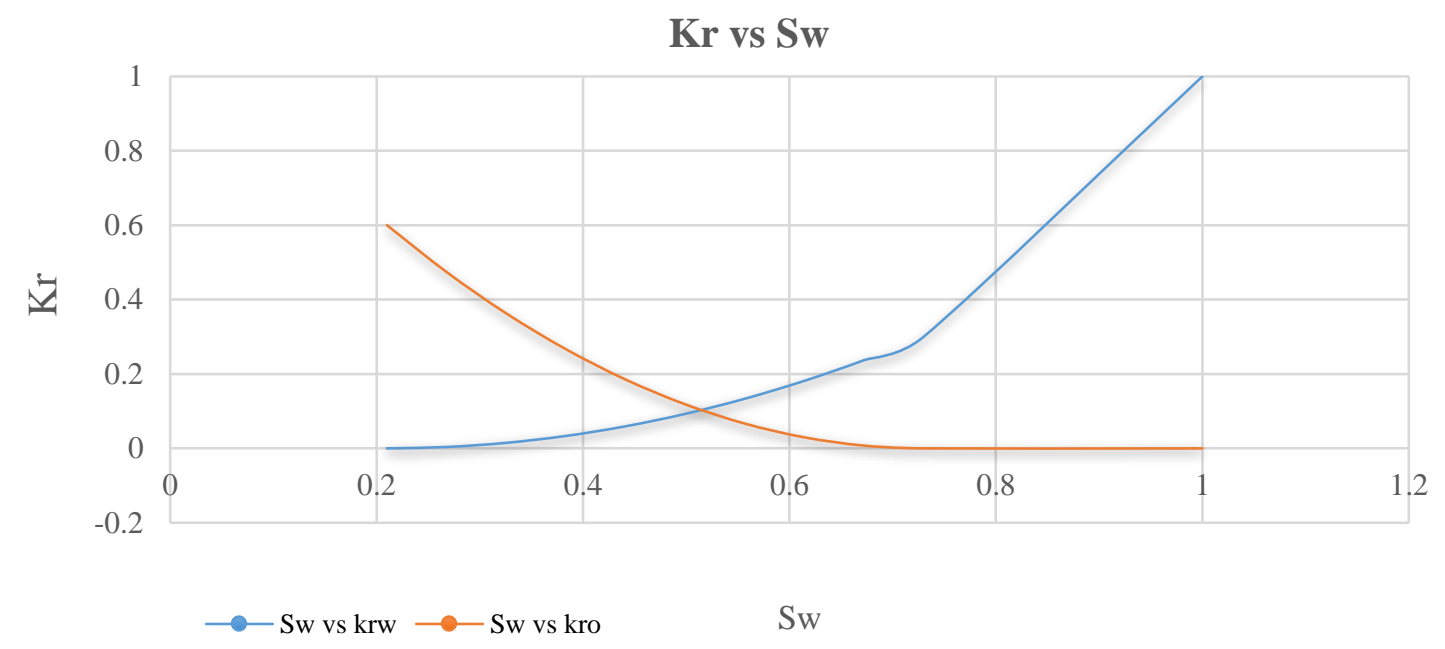

Figure 3. Relative permeabilities of oil-water system.

\subsection{Capillary Pressure}

As mentioned in the previous section the capillary pressure data was not available for Nahr Umr. Capillary pressure determined depending on data of Nahr Umr of Halafya oil field, (Mahdi, 2012), Table 4 and Fig. 4.

Table 4. Capillary pressure and Water saturation of Nahr Umr formation.

\begin{tabular}{|l|l|l|l|l|l|l|l|l|l|l|l|l|}
\hline Sw & 0.07 & 0.15 & 0.23 & 0.31 & 0.3 & 0.47 & 0.55 & 0.63 & 0.72 & 0.79 & 0.87 & 0.9 \\
\hline
\end{tabular}

Pc vs Sw

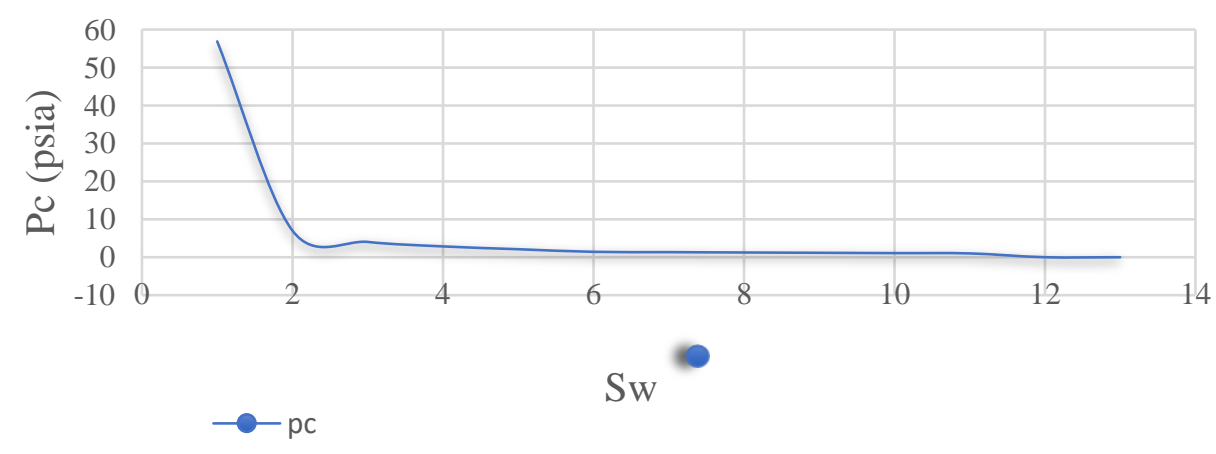

Figure 4. The capillary pressure vs. water saturation. 


\subsection{Fluid Model}

The basic properties of the fluid model include oil viscosity $\left(\mu_{\mathrm{o}}\right)$, solution gas-oil ratio $\left(R_{s}\right)$, oil formation volume factor $\left(B_{o}\right)$, oil density $\left(\rho_{0}\right)$, API gravity and oil compressibility $\left(\mathrm{C}_{\mathrm{o}}\right)$. These data were provided by PVT report, (Gazi et al, 2016), where part of these data was not available so it is obtained by different correlation. PVT data was obtained from Rt-18 file. Water compressibility $\left(\mathrm{C}_{\mathrm{w}}\right)$ was calculated by Biggs and Brill correlation (1978). Mehan in (1980) correlation to estimate the water viscosity was used depending on water salinity (Ahmed, and McDkinney, 2005), Fig. 5, Fig. 6 and Fig. 7.

$$
\mathbf{R}_{\mathrm{S}} \text { vs pressure }
$$

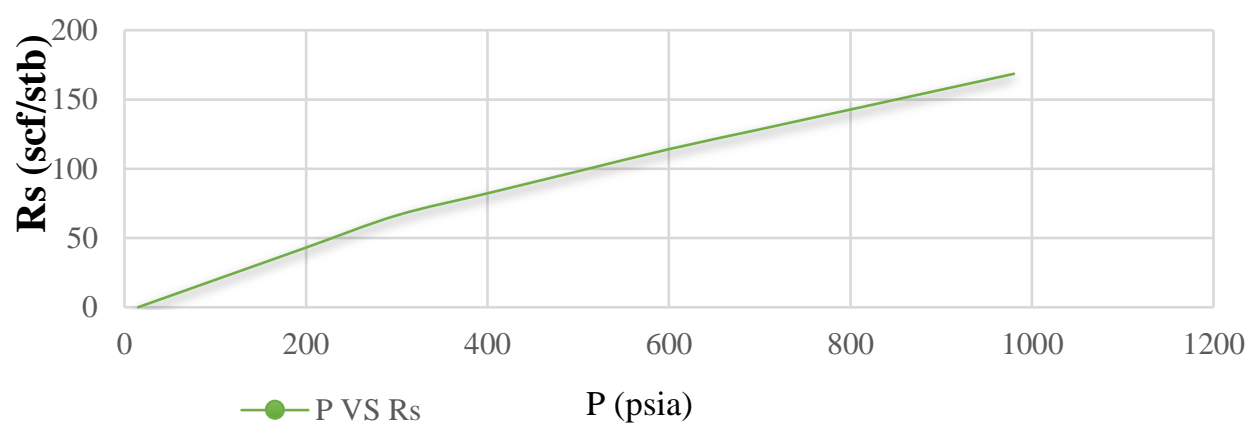

Figure 5. Solution Gas-Oil Ratio vs. Pressure.

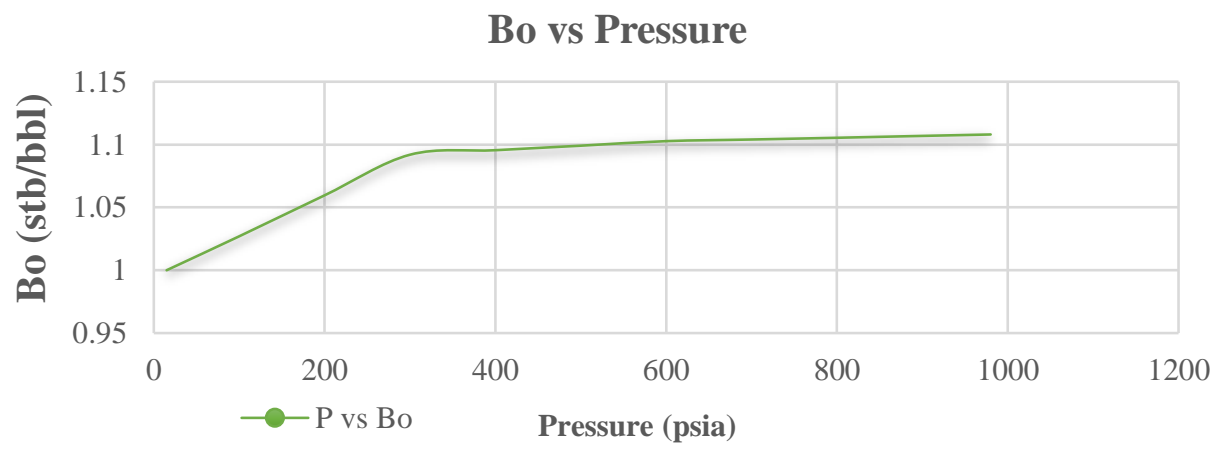

Figure 6. The relation between formation volume factor and pressure. 


\section{Oil density vs Pressure}

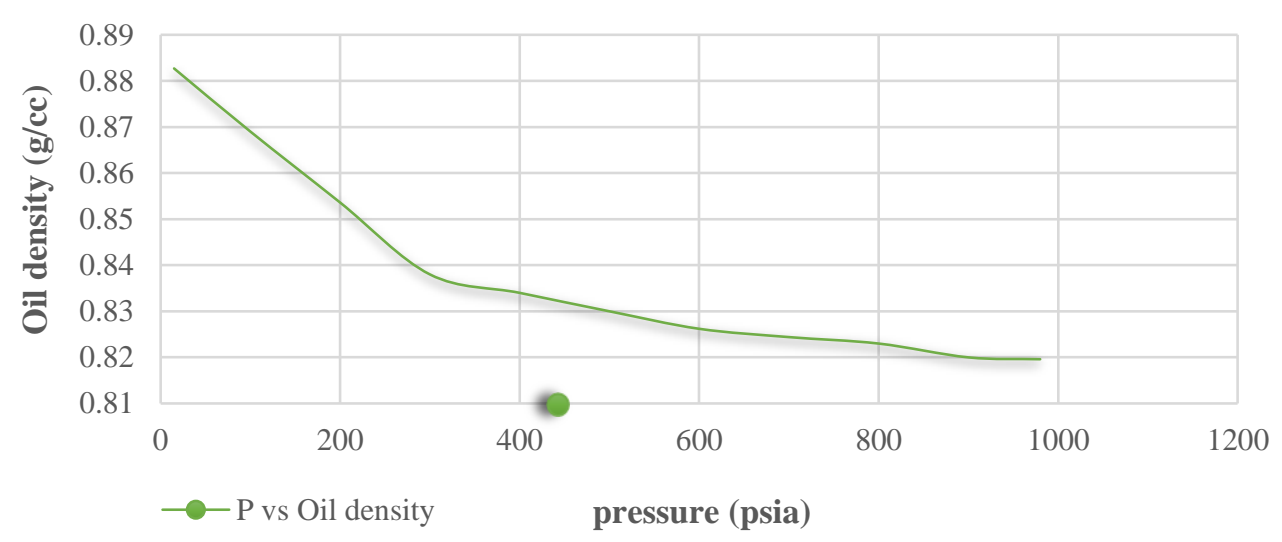

Figure 7. Oil density vs. Pressure.

\subsection{Rock Compressibility}

Newman correlation has been used for obtaining rock compressibility as shown in $\mathrm{Eq}(3)$, (Ahmed, and D.McDkinney, 2005), where average porosity equals to 0.21 , so the resulted compressibility value is $2.568 * 10^{-6} \mathrm{psia}^{-1}$.

$$
C_{f}=\frac{a}{[1+c b \varphi]}
$$

Where

$$
\begin{aligned}
& a=97.32 \times 10^{-6} \\
& b=0.699993 \\
& c=79.8181
\end{aligned}
$$

\section{HISTORY MATCHING}

The matching process is very important to check the validity of the model. Production data has been supported from Basra Oil Company where production data include oil production rate for eight-month (from November 2017 to June 2018) for eight wells (Rt-16, Rt-17, Rt-18, Rt-20, Rt-21, Rt-23, Rt-24, and Rt-27). Several runs have been performed for this study to conduct oil production rate matching. Permeability played a significant role in matching process where the matching was done with multiplying permeability in the x-direction with 1.8, and rock compressibility also affects the matching process. In the beginning, different type of aquifers has used were the best aquifer type was bottom Tracy to get reasonable matching. The pressure matching for Rt-17 shows little difference between measured and calculated. The matching was performed for oil production rate as shown in Fig.8 and Fig.9 for wells Rt 16 and Rt 17. The water cut data was not available for Nahr Umr. Also matching performed on well test pressure for Rt-17, Fig.10, where the yellow line represents the calculated values, and the red point represents the measured value. Keeping in mind the type of aquifer 
used in this case was bottom Tracy aquifer. The input data for this equation was 0.21 for porosity, $200 \mathrm{md}$ for permeability and $360^{\circ}$ for angle.

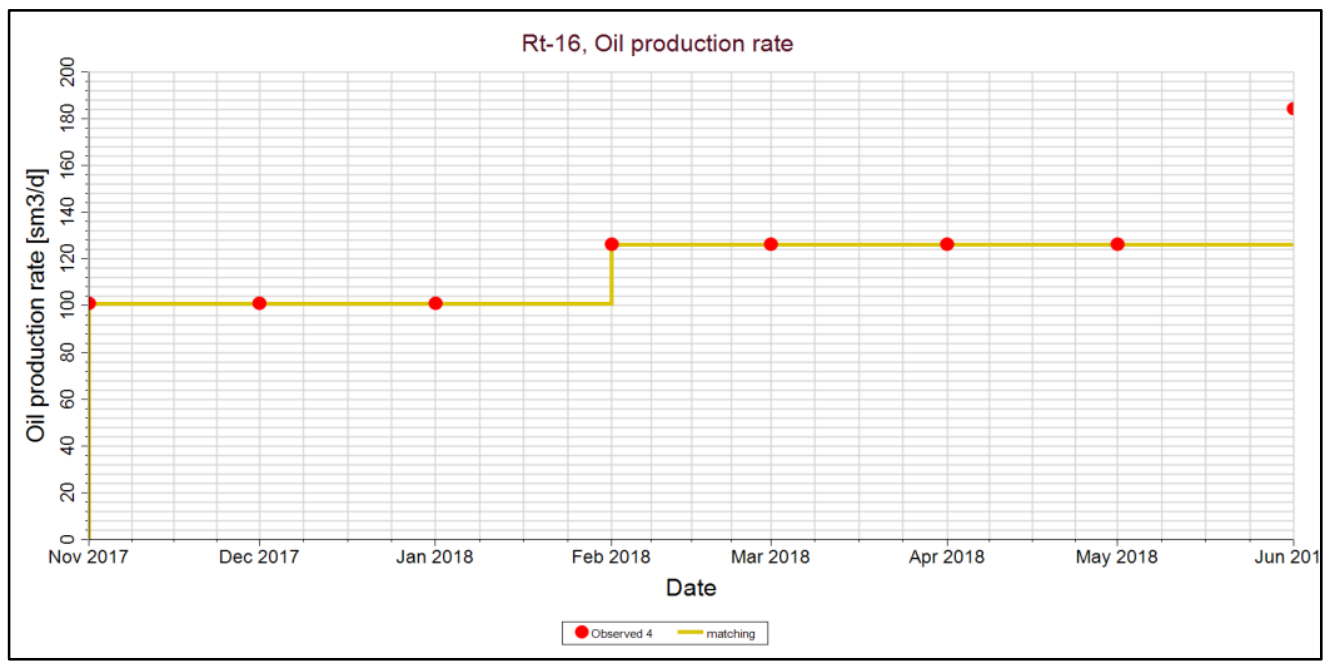

Figure 8. Matching of the oil production rate of Rt-16.

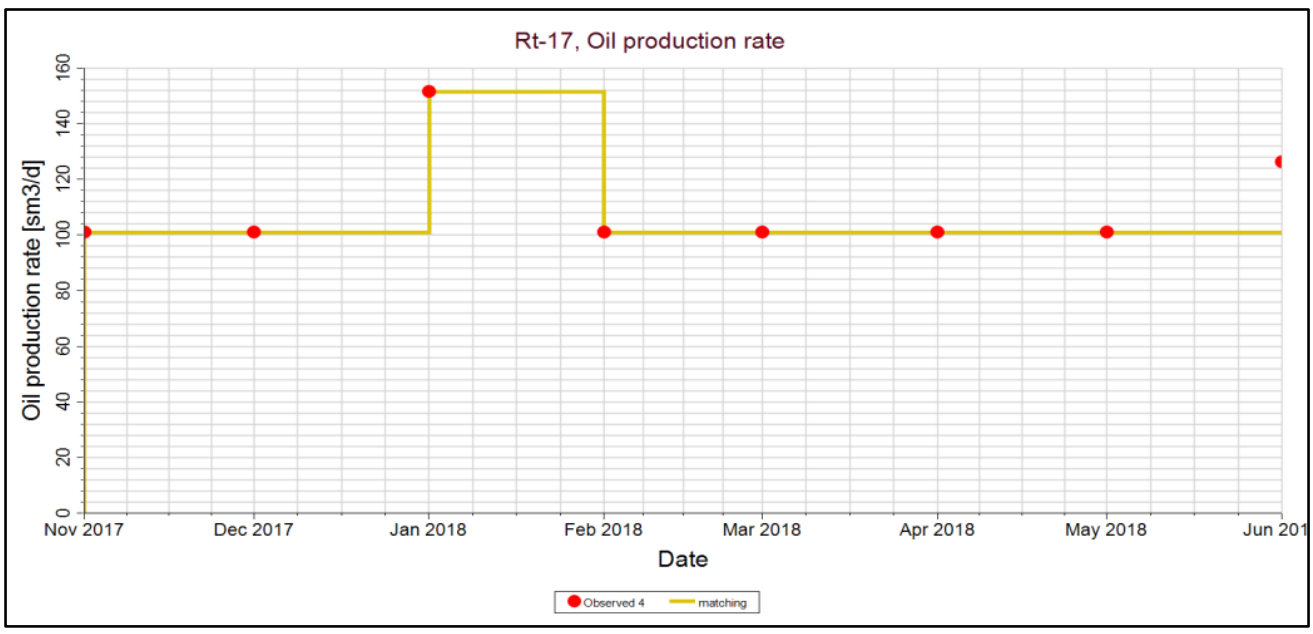

Figure 9.Matching of the oil production rate of Rt-17. 


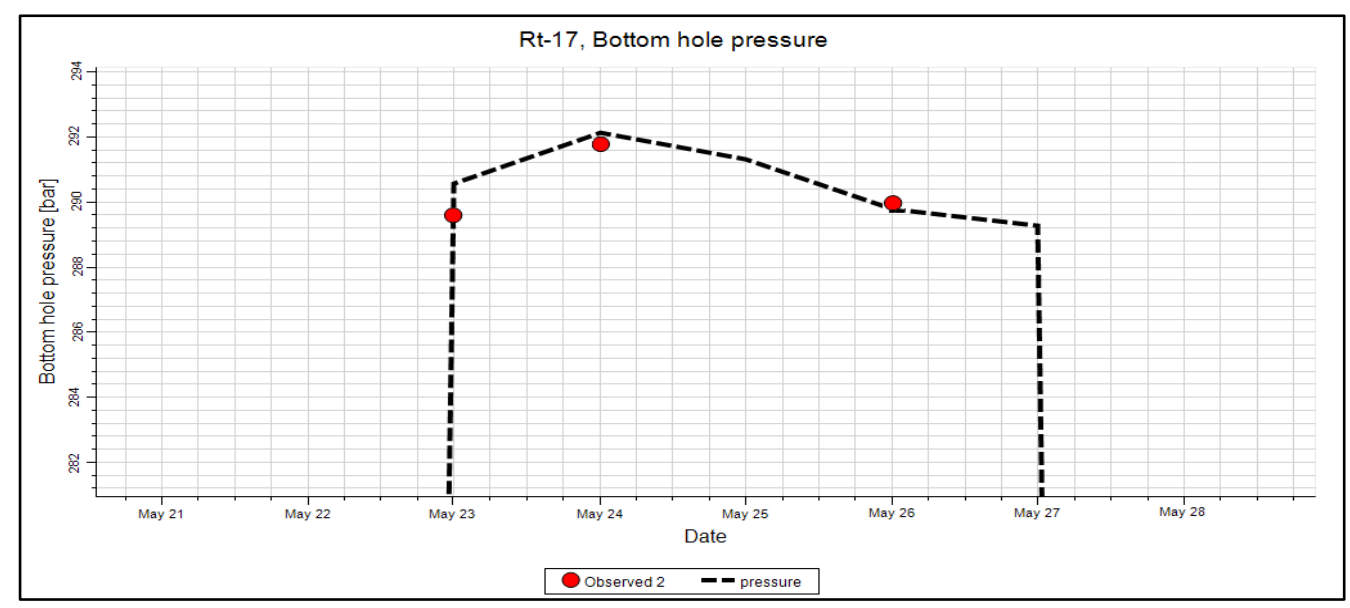

Figure 10. Matching of bottom hole pressure of Rt-17.

\section{DEVELOPMENT STRATEGY}

Several strategies have been proposed in this study where the prediction period was 11 years and five months. The base strategy depended on the existing wells (Rt-16, Rt-17, Rt-18, Rt-20, Rt-21, Rt-23, Rt-24, Rt-22, Rt-26, Rt-27, and Rt-31) where these wells have been run on rate of $57500 \mathrm{bbl} / \mathrm{d}$ which give oil plateau for 1 year, water cut was $16.3 \%$, pressure drop was 600 psi and recovery factor was $0.75 \%$, as shown Fig.11 and Fig.12. Other strategies are summarized below:

\subsection{Case 1; Production with New 22 Vertical Well, 80000 bbl/d.}

This case shows that prediction for 11 years and 6 months with 33 vertical well (22 new well and 11 original well). The case shows that oil plateau was extending for 10 years and 3 months. Water cut was 0.48 at the end of period of prediction of this case where the pressure drop was 43.28 bar (627.72 psi), and the recovery factor was $1.82 \%$.

\subsection{Case 2; Production with New 22 Vertical Well, 100000 bbl/d.}

This case shows that oil plateau extended to for eight years until (1/6/2025) then the oil drops to $6887 \mathrm{~m}^{3} / \mathrm{d}(43317.93 \mathrm{bbl} / \mathrm{d})$. Water cut was 0.55 at the end of the period. Pressure drop was 54.29 bar (787.4 psi) and the recovery factor was $2 \%$.

\subsection{Case 3; Production with New 22 Vertical Well and 125000 bbl/d.}

The production rate of this case was $125000 \mathrm{BBL} / \mathrm{D}$. The oil rate plateau will end at 2/2/2022 (plateau three years and eight months), and oil rate will be $5944.5 \mathrm{~m}^{3} / \mathrm{d}$ (37389.78 bbl/d). Water cut was $63 \%$ at the end period of prediction. Pressure drop was 66.96 bar (971.17 psi). Recovery factor was $2.08 \%$.

Fig.13 and Fig.14 show the results of cases 1, 2, and 3. 


\subsection{Case 4; Production with New 33 Vertical Well and 5 Horizontal, 80000 bbl/d.}

In this case, 44 vertical well has been used (new 11 well) besides five horizontal well (H-1, H-2, H-3, H-4, and H-5) that proposed to be drilled in the reservoir. The case shows that oil plateau was extended to 11 year and 6 months, water cut was $50 \%$, pressure drop was 43.28 bar (627.723 psi), and oil recovery was $1.85 \%$ at the end of the period of prediction.

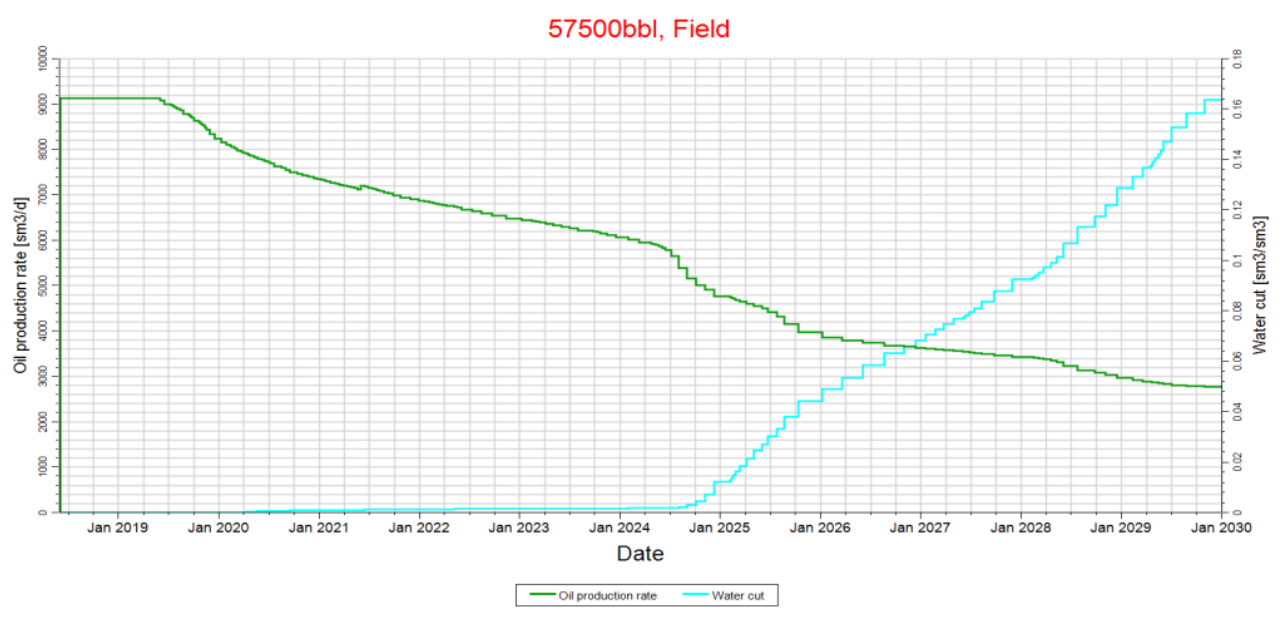

Figure 11. The original case (oil production and water cut).

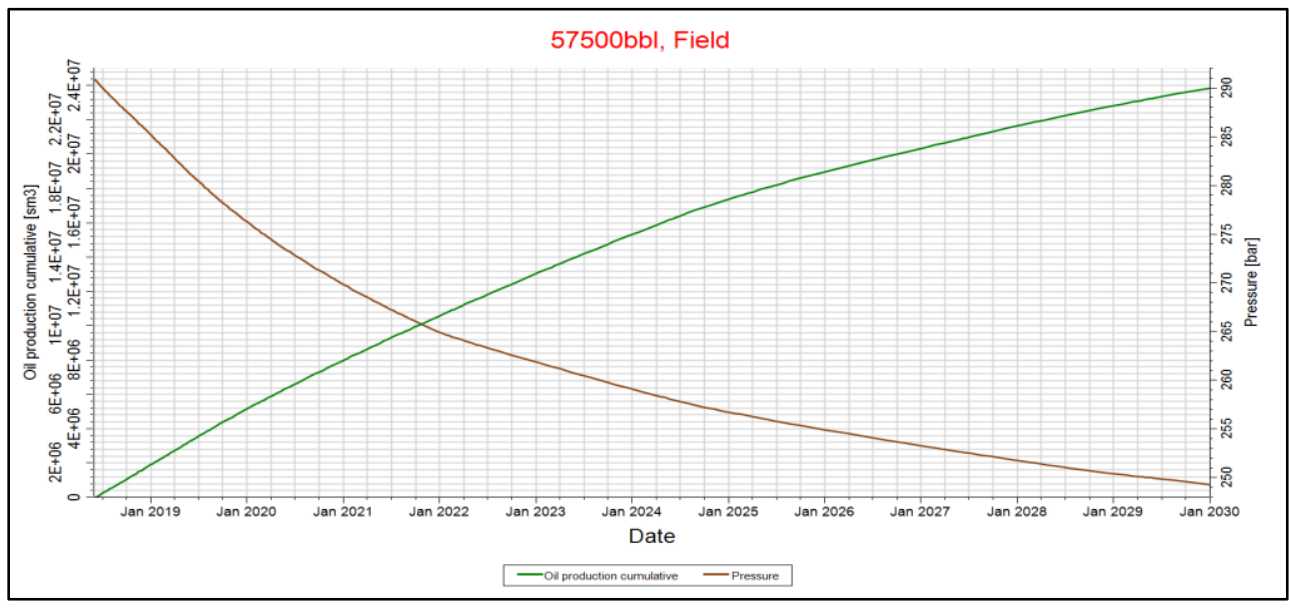

Figure12. The original case (Pressure and Oil Cumulative). 


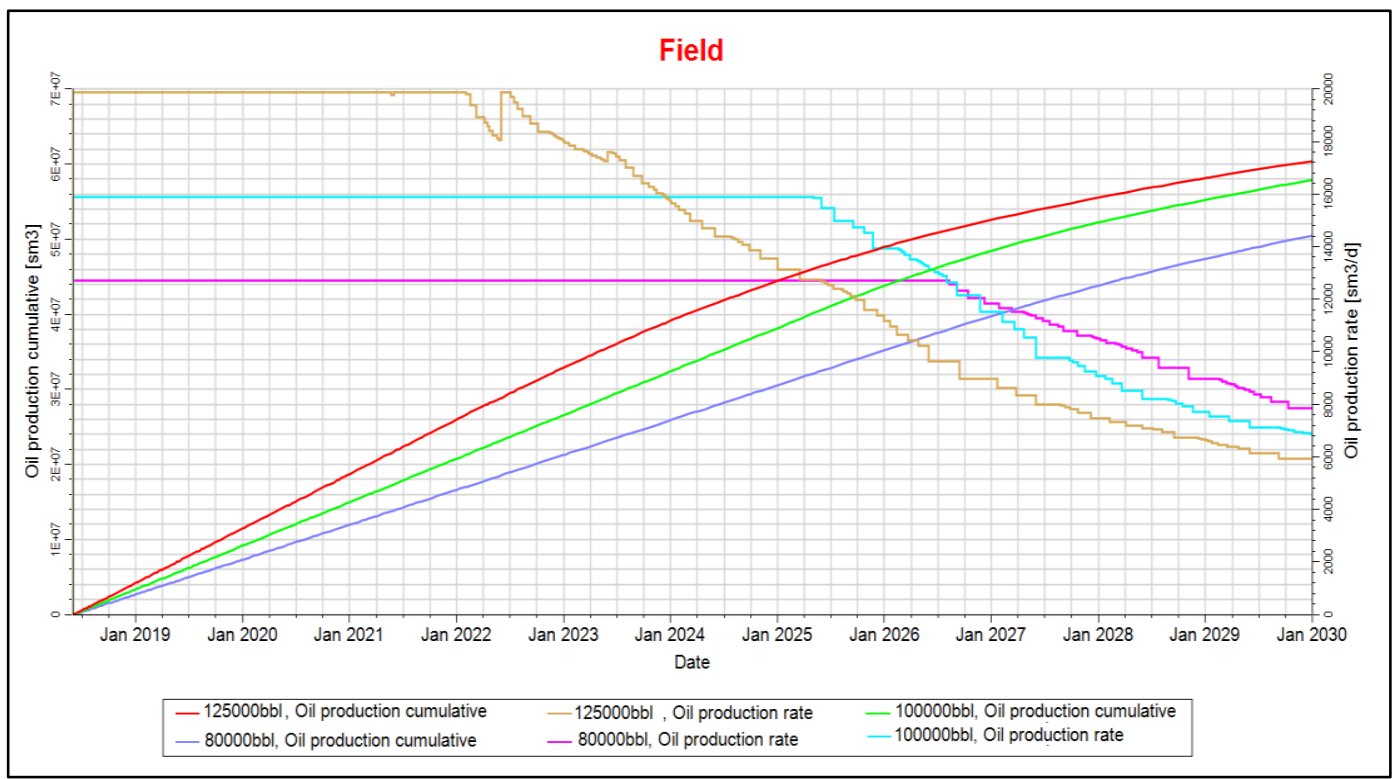

Figure 13. Cumulative and oil production rate of Cases (1,2 and 3)

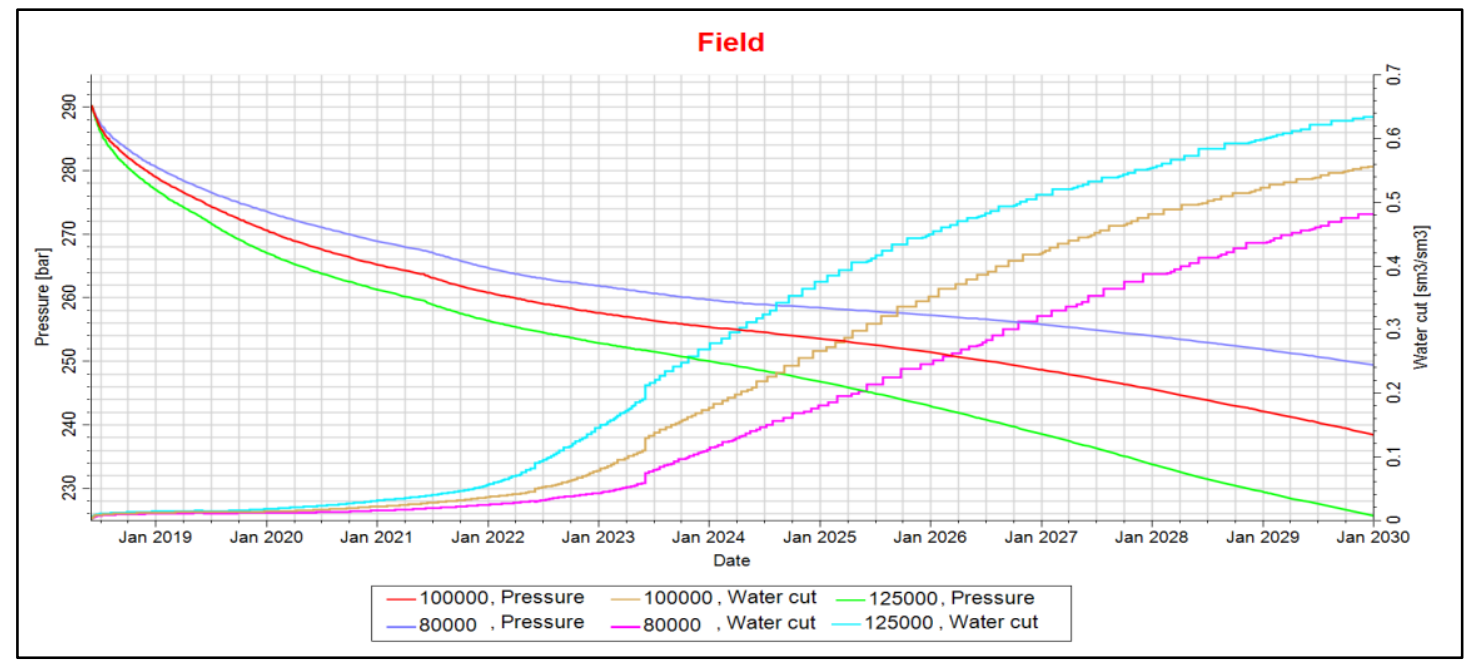

Figure 14. Pressure and Water cut of Cases (1,2 and 3)

\subsection{Case 5; Production with New 33 Vertical Well and 5 Horizontal, $100000 \mathrm{bbl} / \mathrm{d}$.}

This case shows the plateau was extended to the entire period of prediction which was 11 years and 6 months where the water cut was $60 \%$ at the end of period. Pressure dropped to 239.32 bar (3471.04 psi), and oil recovery was $2.3 \%$. 


\subsection{Case 6; Production with New 33 Vertical Well and 5 Horizontal, 125000 bbl/d.}

The plateau of oil also continued for 11 years and 6 months (full period) where the rest results were; the water cut was $63 \%$, pressure dropped to 224.36 bar( 3254 psi), and oil recovery was $2.9 \%$ at the end of prediction.

\subsection{Case 7; Production with New 33 Vertical Well and 5 Horizontal, 150000 bbl/d.}

This case shows the plateau of oil was 9 years and 7 months where the plateau of oil stopped at 5/1/2028 and became $18230 \mathrm{~m}^{3} / \mathrm{d}(114663 \mathrm{bbl} / \mathrm{d})$ at $16 / 9 / 2029$. Water cut was $71 \%$, the pressure drop was 82 bar (1189.3 psi), and the oil recovery was $3.4 \%$.

The results of the cases 4, 5, 6, and 7 are shown in Fig.15, Fig.16. The locations of the proposed wells can be seen in Fig.17.

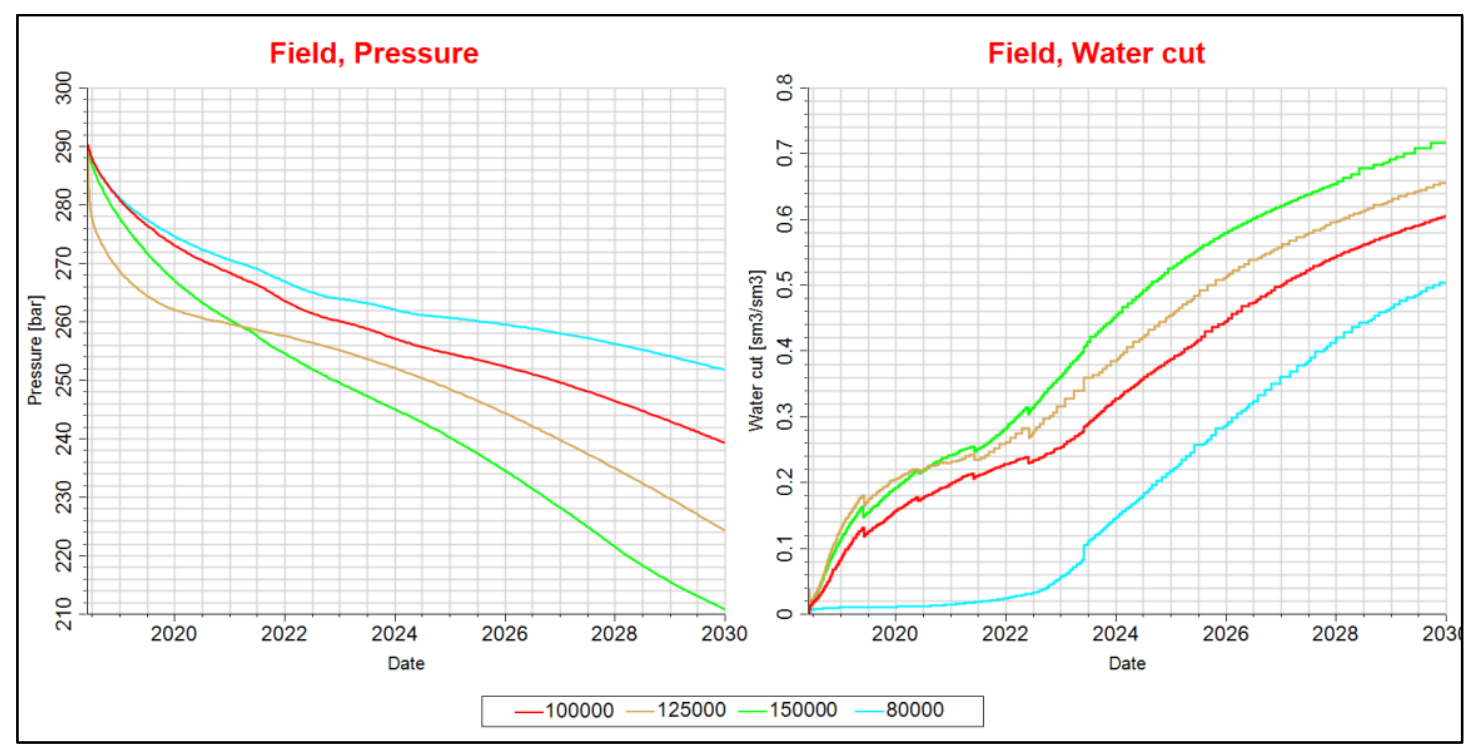

Figure 15. Pressure and Water Cut of Cases (4,5,6 and 7). 


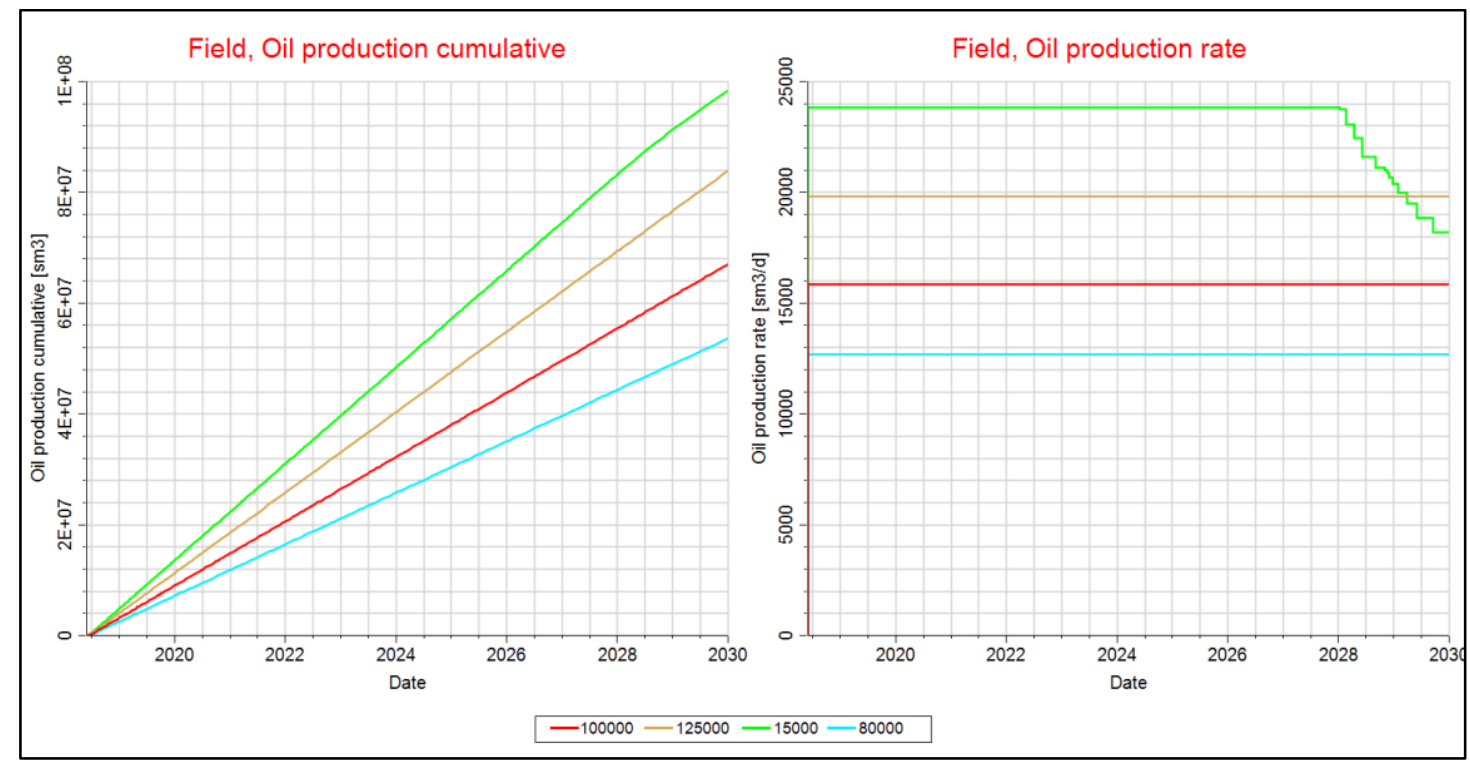

Figure 16. Pressure and Water Cut of Cases (4,5,6 and 7).

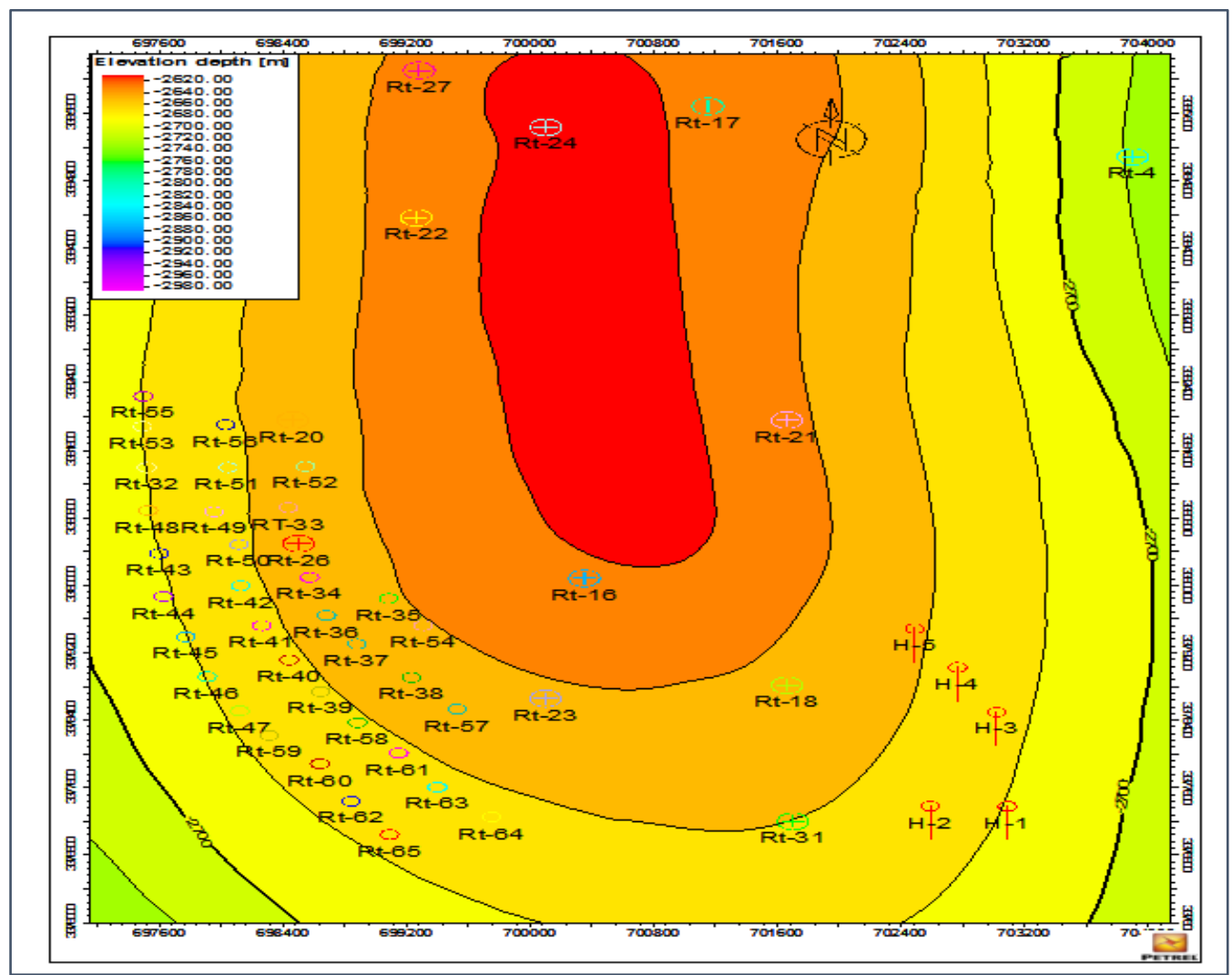

Figure 17. Locations of original and proposed wells.

\section{CONCLUSIONS}

1- The permeability of the reservoir under study was found to be the most effective parameter that controls the matching process. 
2- Many strategies have been proposed for Nahr Umr Formation using the existing and new wells. The best-case depended on adding 33 new to the 11 original vertical wells beside 5 horizontal wells which gave oil plateau for 9 years and 7 months where water cut, recovery factor, and pressure values were $71 \%, 3.4 \%$, and 1189.3 psi respectively. The new wells have been distributed in high permeability regions.

3- Waterflooding is not recommended due to high water cut obtained during natural depletion.

\section{NOMENCLATURE}

$\mathrm{C}_{\mathrm{f}}$ : formation Compressibility $\mathrm{Psi}^{-1}$.

$\mathrm{C}_{\mathrm{w}}$ : water Compressibility in $\mathrm{psi}^{-1}$.

$\left(\mathrm{k}_{\mathrm{ro}}\right)_{\text {swi: }}$ oil relative permeability at residual water saturation.

$\mathrm{k}_{\mathrm{rw}}$ : water relative permeability.

$\left(\mathrm{k}_{\mathrm{rw}}\right)_{\text {sorw: }}$ water relative permeability at residual oil saturation.

$\mathrm{S}_{\mathrm{wi}}$ : irreducible water saturation

WOC: water-oil contact

$\mathrm{Y}$ : water salinity at ppm.

$\mu_{\mathrm{w}}$ : water viscosity cp.

$\mu_{\mathrm{wd}}$ : water viscosity at standard condition.

\section{REFERENCES}

- Al-Aruri, A., Al-Suwailem, M., Al-Otaibi, S., Al-Mutairi, S., Pederson, K., Aldajani, S. and Garwan, A., 2015, Devising and Optimizing Development Strategies for South Fuwaris Field Using Integrated Reservoir Simulation Models. In SPE Saudi Arabia Section Annual Technical Symposium and Exhibition. Society of Petroleum Engineers.

- Doaa S. Mahdi, 2012, Miscible Flooding For Nahr Umr Reservoir/Halfaya Oil Field, University of Baghdad.

- -Dogru, A.H., Saudi Arabian Oil Co, 2019, Sequential fully implicit well model with tridiagonal matrix structure for reservoir simulation. U.S. Patent Application 10/175,386.

- Hussian S.Hussian, Gassan A.Majeed, and Malik H.Mohmood, 2016, Well test report of Ratawi of Rt-16, South Oil Company.

- Jassim Gazi, Ahmed Ibrahim, Mayea Khalaf, Adee N. Hassan, and Ahmed R. Fahed, 2016, Complete Pvt study of Nahr Umr reservoir/well no.18.

- Joint and Training between Ministry of oil and JOGEMEC,2007, Geological study for Ratawi oil field. 
- Mollaei, A. and Delshad, M., 2019, Introducing a novel model and tool for design and performance forecasting of waterflood projects. Fuel, 237, pp.298-307.

- Morris, and Beggs, 1967, Using log-Derived of water saturation and porosity, SPWALA $8^{\text {th }}$ Annual logging symposium.

- Schlumberger, 2018, Petrel software manual online.

- T.Ahmed, and D.McDkinney, 2005. Advanced Reservoir Engineering, reservoir fluid properties. 